\title{
Science Education in Kenya
}

\section{Ochong' Okelo}

\section{Introduction}

S C I E N T I F I C F A C TS and principles are basically culture free; but their interpretation, teaching, and application are not always necessarily free of culture. In addition to this general intranational cultural milieu, there are those whose chosen beliefs are either contradicted or threatened by scientific methods, facts, and theories and, therefore, seek to force the science educators to teach or otherzvise include such beliefs in the teaching of science. Given the past track records of such beliefs and science, there is no doubt that science will ultimately triumph.

This paper briefly presents the structure and organization of science education from preschool (preprimary) to university level. It also addresses such sociocultural issues as religion and acceptance or resistance to science by the Kenyan society.

\section{Organization and Structure of Science Education in Kenya}

Science education is currently broadly structured as follows:

three years of preschool (preprimary)

eight years of primary school science

four years of secondary / high school science

four years of university (for basic bachelor of science degree)

\section{PRESCHOOL SCIENCE}

Science education begins in preschool as a diffuse, amorphous introduction of simple scientific concepts through informal but guided activities. The role of the teacher, at this stage, is to provide the facilities and an environment that promote informal exploration and experimentation during class activities. 
Although no formal, organized, and structured science is being taught, activities and opportunities to play, explore, and experiment are made available and help introduce the learners (three-, four-, and fiveyear-old children) to concepts that can only be appropriately termed "prescience."

\section{PRIMARY SCHOOL SCIENCE}

At the primary school level, the teaching of the scientific concepts introduced during preschool education are further explored in a less formal setting. The concepts are organized and presented as units. For the first three years of the primary school (grades one, two and three), there are twelve units per year. For the upper primary classes (grades four through eight), there are seven units per year. A unit, in this context, refers to a topic to be covered in teaching. The lower primary represents a progressive transition from preschool "science" to a more detailed and relatively advanced treatment of the topics in upper primary. As the topics become more detailed in the upper primary, the student is given an indication of the discipline-based structure of the secondary school.

follows:

\section{SECONDARY SCHOOL}

Science education is compulsory for all students and is structured as follows:

four years of biology

four years of chemistry

four years of physics

\section{UNIVERSITY SCIENCE}

Science is split into discipline as follows:

four years of botany

four years of biochemistry

four years of chemistry

four years of geology

four years of physics

four years of zoology 
Each discipline can be studied alone (e.g., botany) or in combination with one other (e.g., botany and chemistry) for a four-year bachelor of science degree. In addition the university offers degrees in sciencebased disciplines such as crop science, animal production, soil science, home science, forestry science, medicine, pharmacy, and microbiology.

At master's and doctoral degree levels, each of the above disciplines is split into specialized areas (e.g., zoology: cell and molecular biology; genetics; immunology; endocrinology, and so on).

\section{Difficulties Faced by Science Educators}

A brief account of the changes that have occurred in the education system since 1963 will help understanding of some of the difficulties faced by science educators in Kenya.

At the time of its independence in 1963, Kenya had 6,058 primary and 151 secondary schools, with pupil enrollments of 891,553 and 30,121 respectively. For the primary schools there were 17,682 trained and 5,045 untrained teachers, resulting in a pupil:teacher ratio of 39.2:1. For the secondary schools there were 1,602 (1,098 trained and 504 untrained) teachers. At the same time Kenya faced a severe shortage of skilled personnel required to take over the many responsibilities that had been held by foreigners up to the time of independence. The shortages were particularly severe in science and technical areas. To deal with these shortages the country effected a tremendous expansion in primary, secondary, and tertiary education. For example, by 1974, the number of secondary schools had increased to 1,019 .

Although the shortages were largely met in the 1970s, the tempo of educational expansion continued into the early 1990 . The tremendous expansion has not affected the quality of science education in schools that were established by the late 1970 s. For most schools established in the 1980 s and later, the science educators face problems of poor infrastructure (e.g., lack of good laboratories, scientific equipment, current scientific publications, and, in some cases, even laboratory reagents). 
Until the second half of the 1980 s, the universities were not affected by the consequences of the tremendous expansion of the science education in primary and secondary schools. However, by 1988 the number of undergraduate science students had increased about tenfold, but without any increase in laboratory space, teaching equipment, or number of faculty. At the same time, the economic situation in the country was worsening and the science educators were finding themselves unable to afford subscriptions to scientific publications (e.g., journals) or keep up payments for membership in their professional organizations. These difficulties were already being experienced by science educators in most state-supported universities in East, Central and West Africa. These difficulties have persisted and have contributed to the brain drain seen in Kenya, Botswana, Namibia, Republic of South Africa, Lesotho, and Zimbabwe.

In addition to those infrastructural difficulties, the science educators in Kenya, particularly at the tertiary level, face the problem of lack of funds for scientific research. In this connection, it is informative to note that in 1980 Africa as a whole spent only 0.28 percent of its GNP on scientific research (UNESCO Statistical Yearbook, 1992). This stands in sharp contrast to Asia and North America, which, during the same year, spent 1.40 percent and 2.23 percent respectively. Ten years later the expenditure on science by African countries (excluding the countries of North Africa) had dropped to 0.25 percent of the GNP. During the same period, the expenditure on science by Asia and North America had increased to 2.05 percent and 3.16 percent respectively (UNESCO Statistical Yearbook, 1992).

\section{Is There Resistance to Science in Kenya?}

That science is a potentially very productive force is generally recognized, and there is no evidence of resistance to it in Kenya or any other African country. The national educational curricula give it a great deal of emphasis, and all the state universities have faculties/schools of science with elaborate physical facilities for both teaching and research. However, for most of the population basic scientific research is still regarded as the concern of the scientific community alone, because 
research is perceived as having no relation to production. The majority of the population do not yet understand the potential value of basic scientific research; in their perception, basic researchers are academically inclined theoreticians with little or no practical ability. The mission and effort of the basic scientific research is to understand natural phenomena, systematically and rationally, in order to discover new concepts and create new theories and ways of explaining nature. In the face of rising unemployment and unrealized socioeconomic dreams, the majority of the population regard this mission as an unnecessary waste of time and money.

A good indicator of the magnitude of acceptance of science is seen in the records of about ten thousand candidates who apply for admission into the five public universities each academic year. About 68 percent of the applications are for science and science-based degree programs. Of the six public university institutions in Kenya, three are for the study of science and technology and a fourth (University of Nairobi) has more than half of its degree programs in science and technology.

In addition to the institutions in the education system there are many research institutions, including Kenya Medical Research Institute (KEMRI); Kenya Agricultural Research Institute (KARI); Kenya Marine and Fisheries Research Institute (KMFRI); Kenya Forestry Research Institute (KEFRI); Tea Research Foundation; Coffee Research Foundation; African Medical Research Foundation (AMREF); International Center for Insect Physiology and Ecology (ICIPE); Kenya National Academy of Science; and African Academy of Sciences. The fact that these institutions exist and operate freely in Kenya is clear evidence that there is no resistance to science.

\section{Science and the Traditional Culture}

The traditional African culture of Kenya is compatible with modern science, and African people experience no cultural barrier in accepting science. In fact, some aspects of the traditional African culture, such as the omnipresence of water in the African cosmogonies (dating back to $\mathrm{NnW}$ of ancient Nubia and Kamet), are in resonance with the concept 
of the "primitive ocean" placed by modern science at the early stages of chemical evolution.

An important concept in the traditional culture of Kenya and many other African countries is that of person-in-community, not person as an individual, alone and alienated. This concept is summarized in the African dictum "I am because we are and, because we are, therefore, I am." In other words, a person is really a moral agent whose identity, purpose, and direction arise from and through his or her community. This concept does not reject science but expects scientific achievement to be for the good of the community. It is for this reason that, in spite of Kenya's holistic, integrative view of life and the universe, science has been accepted and supported.

\section{Science and Religion}

A number of religions, including African traditional, Christianity, and Islam, are practiced in Kenya; but only Christianity seems to be aggressively in conflict with science. Christianity seeks to impose its story of creation in the teaching of science. Fundamentalist Christians not only have sought to censor science textbooks but also have fought to have Christian mythology about the origins of the universe replace or otherwise be taught by scientists alongside the theory of evolution. Most African traditional religions place primordial uncreated matter (i.e., primeval water) at the beginning of beginnings and, therefore, before God the Creator and Engineer. In this context, the universe and God are distinct, with the universe being anterior to the Creator. That matter can and did evolve independently of the Creator, therefore, is not regarded as a threat to the beliefs.

Evolution is not the only point of conflict between the Christian religion and science. Biology of human reproduction, especially contraception, in vitro fertilization, and sex education, constitute other areas of major conflict. Research and experimentation in these areas are condemned by the Christian church. In addition, genetic engineering, whether under the name of gene manipulation, cloning, or recombinant DNA technology, is another point of conflict between science and Christianity. Some Christian fundamentalists have even 
insisted that classes on human anatomy be taught that a skeleton of a male can be distinguished from that of a female by counting the number of ribs, as the former will be found to have one less rib!

\section{Effect of Science on Society}

Science, with its sibling, technology, is already playing a key role in economic and social development. Science is proving to be a powerful tool in promotion of social progress and efforts to provide a better standard of living for the population. These effects of science are already being felt in agriculture, health, environment, population growth rate, and communication. A few examples are cited below.

In agriculture, the best example that demonstrates the effect of science on Kenyan society has been the production of maize varieties that do well in the arid and semiarid parts of Kenya. Hybridization and chromosome engineering by Kenyan applied research scientists have produced maize varieties that are fast growing and do not require as much rain and time as the original varieties. Another product of genetic manipulation: Is a fast-growing, high-yield variety of banana developed by scientists from jomo Kenyatta University of Agriculture and Technology. The new variety is already being supplied to farmers and others.

In the area of health, a team of medical scientists has successfully carried out kidney transplants for some years. In addition, biological research scientists have come up with herbal extracts that are proving quite effective against malaria vectors, the mosquito. The extracts are applied to mosquito nets and remain effective for six months. An environmentally safe insecticide has now been produced from trees of the family Meliaceae.

Science is helping raise the level of environmental awareness, and people are beginning to take positive steps (e.g., tree planting, agroforestry) to fight desertification, soil erosion, and water pollution. In addition, Kenya's population growth rate, once ranked the highest in the world, has started to show some decrease.

As Kenya strives to enhance its scientific and technological capacity, there is a growing realization that no meaningful economic and social 
development can take place unless and until this capacity attains some credible level on a world scale.

\section{References}

Ministry of Education, Science and Technology, 1993. Guidelines for Preschool Education Jomo Kenyatta Foundation, Nairobi, Kenya. 8-4-4-System of Education, 1984. The Government Printer, Nairobi, Kenya.

UNESCO Statistical Yearbook, 1992. Paris, UNESCO.

Republic of Kenya, 1988. Report of the Presidential Working Party on Education and Manpower Training for the Next Decade and Beyond.

Acknowledgement

I wish to acknowledge, with thanks, the assistance received from Mrs. Pamela Dacha and Mr. Stephen P. Otuchi in the preparation of this manuscript. 